\title{
Influence of Culture Media and Temperature on Growth and Sporulation of Lasiodiplodia theobromae, Pestalotiopsis microspora and Fusarium oxysporum Isolated from Ricinodendron heudelotii in Cameroon
}

\author{
Joseph Djeugap Fovo ${ }^{1}$, Daniel Dostaler ${ }^{2}$ and Louis Bernier ${ }^{3}$ \\ ${ }^{1}$ Phytopathology Laboratory, Department of Plant Protection, Faculty of Agronomy and \\ Agricultural Science, University of Dschang, Box 222 Dschang, Cameroon \\ ${ }^{2}$ Plant Pathology Laboratory, Department of Phytology, Faculty of Agricultural Science and \\ Food, Université Laval, G1V 0A6 Qc, Québec, Canada \\ ${ }^{3}$ Forest Pathology Laboratory, Department of Wood science and Forest, Faculty of Forestry, \\ Geography and Geomatic, Université Laval, G1V 0A6 Qc, Québec, Canada \\ *Corresponding author
}

\begin{tabular}{|c|c|}
\hline & B S T R A T \\
\hline $\begin{array}{l}\text { Ke y w o r d s } \\
\text { Pestalotiopsis } \\
\text { microspora, } \\
\text { Lasiodiplodia } \\
\text { theobromae, } \\
\text { Fusarium } \\
\text { oxysporum, } \\
\text { Culture media, } \\
\text { Temperature, } \\
\text { Mycelial growth, } \\
\text { Sporulation, } \\
\text { Ricinodendron } \\
\text { heudelotii. }\end{array}$ & $\begin{array}{l}\text { The effects of mycological media and temperature on mycelial growth and spore } \\
\text { production of three fungal pathogens recently reported on Ricinodendron heudelotii were } \\
\text { investigated. The pathogens were identified on the basis of the ITS sequences of their } \\
\text { ribosomal DNA as Pestalotiopsis microspora (isolate PMHP_109L), Lasiodiplodia } \\
\text { theobromae (isolate LTHP_110L) and Fusarium oxysporum (isolates FOBR_164S, } \\
\text { FOBR_049L and FOHP_121L). The radial growth (mm/day) of the fungi and conidia } \\
\text { concentrations (number of conidia/ml of suspension) were assessed on three culture media: } \\
\text { potato dextrose agar (PDA), malt extract agar (MEA) and } \mathrm{V}_{8} \text { juice agar }\left(\mathrm{V}_{8}\right) \text {. All media } \\
\text { were suitable for the growth of } L \text {. theobromae while } \mathrm{V}_{8} \text { juice agar supported the fastest } \\
\text { mycelial growth rate in } P \text {. microspora }(13.4 \mathrm{~mm} / \mathrm{day}) \text {. PDA and MEA media were } \\
\text { appropriate for } F \text {. oxysporum. The growth rate and conidia concentration increased with } \\
\text { temperature and attained their optimum at } 23^{\circ} \mathrm{C} \text { for } P \text {. microspora and } L \text {. theobromae and } \\
28^{\circ} \mathrm{C} \text { for Fusarium oxysporum strains. There was no growth of } P \text {. microspora and } L \text {. } \\
\text { theobromae at } 33^{\circ} \mathrm{C} \text { while at this temperature, Fusarium oxysporum strains continued to }\end{array}$ \\
\hline Article Info & grow and produce spores. The best temperature for spore production was $23^{\circ} \mathrm{C}$ for $P$. \\
\hline $\begin{array}{l}\text { Accepted: } \\
29 \text { May } 2017 \\
\text { Available Online: } \\
10 \text { June } 2017\end{array}$ & $\begin{array}{l}\text { isolates produced the highest concentration of conidia in all the culture media. These data } \\
\text { contribute to the knowledge of the biology of these newly recognized parasitic fungi on } R \text {. } \\
\text { heudelotii and show that species like } F \text {. oxysporum possesses a high level of phenotypic } \\
\text { plasticity that allows it to survive and proliferate over a wide range of environmental } \\
\text { conditions. }\end{array}$ \\
\hline
\end{tabular}

\section{Introduction}

Ricinodendron heudelotii Pierre ex Heckel belongs to family Euphorbiaceae and is endemic to Madagascar and the Congo Basin forests of Africa. Its roots, bark, leaves and seeds are used by local people for medicine and food (Yeboah et al., 2011). It was also established that the species has a high agroforestry potential (Djeugap et al., 2013) 
and yearly income from the sale of its edible grains in Cameroon is estimated to 1,556,280 US dollars (Perez and Ndoye, 1999). In Cameroon, many fungi cause various diseases on Ricinodendron heudelotii in forests, agroforestry systems and nurseries. Disease symptoms commonly encountered include leaf spots, leaf and seed rot and shoot blight (Djeugap, 2013; Djeugap et al., 2016). Despite these food, medicinal and agroforestry properties, very little work has been devoted to the study of pathogens responsible to these diseases. It is known that fungi can grow and reproduce in or on diverse culture media requiring several specific nutrient elements. They are isolated on specific culture medium for cultivation, preservation, microscopic examination and biochemical and physiological characterization. Also, a wide range of media are used for isolation of different groups of fungi that influence the vegetative growth and colony morphology, pigmentation and sporulation depending upon the composition of specific culture medium, $\mathrm{pH}$, temperature, light and water availability (Kuhn and Ghannoum, 2003; Kumara and Rawal, 2008). However, requirements for fungal growth are generally less restrictive than for sporulation. The aim of this work was to assess the growth and sporulation of three cosmopolitan and polyphagous fungi, namely Pestalotiopsis microspora, Lasiodiplodia theobromae and Fusarium oxysporum, recently isolated from $R$. heudelotii in Cameroon (Djeugap, 2013) on three culture media at five temperatures. Several studies have shown that $P$. microspora is responsible for leaf spots, dieback and fruit rots in various plant species around the world (Keith et al., 2006; Djeugap et al., 2009; Zhang et al., 2010). The pathogen $L$. theobromae infects more than 500 plant species on which it causes root and fruit rots, shoot blight, dieback and canker (Mohali et al., 2005; Gezahgne et al., 2014; Djeugap et al., 2016). It was established that
F. oxysporum is responsible for diseases such as seed rots and wilt in many crop and woody plant species (Tantawi and Fernandez, 1993; Hussain et al., 2012). This study was conducted with a view to contribute to the knowledge of the biologyof $P$. microspora, $L$. theobromae and $F$. oxysporum, three newly recorded fungi isolated from $R$. heudelotii.

\section{Materials and Methods}

Sample collection, isolation and identification of fungi

Infected leaves and stems of $R$. heudelotii seedlings were collected in natural forests and nurseries of the World Agroforestry Centre in Cameroon. Isolation of fungi was carried out on potato dextrose agar medium (PDA) supplemented with ampicillin at $250 \mathrm{mg} / \mathrm{ml}$ at $22^{\circ} \mathrm{C}$ for 10 days (Djeugap, 2013). Then, the pure cultures were transferred on PDA plate with cellophane membrane for 10 days. The mycelia were harvested, frozen in liquid nitrogen and crushed to a fine powder. Genomic DNA was extracted using the DNA Mini Kit Plant protocol (Qiagen) (Griffin et al.,2002; Levy and Mavrodieva, 2004), resuspended in TE buffer (10 mM Tris- $\mathrm{HCl}, 1$ $\mathrm{mM}$ EDTA, $\mathrm{pH}$ 8) and the concentration of DNA was determined with a spectrophotometer. Purified diluted DNA was used as template for the amplification of the internal transcribed spacer (ITS) of nuclear ribosomal RNA gene (rDNA) repeats with the universal ITS4 (TCCTCCGCTTA TTGATATGC) and ITS5 (GGAAGTAAAA GTCGTAACAAGG) primers (White et al., 1990). The total volume of the PCR reaction was $25 \mu 1$ made up of $1.2 \mu l$ of each primer, $12.5 \mu 1$ of Premix ExTaq, $5 \mu 1$ of diluted DNA and $5.1 \mu 1$ of double sterile distilled water. Amplification was performed in a PTC-225 Thermal Cycler (MJ Research, MA, USA) as follows: DNA denaturation $\left(94^{\circ} \mathrm{C}, 2 \mathrm{~min}\right)$; annealing $\left(70^{\circ} \mathrm{C}, 2 \mathrm{~min}\right)$ and final extension 
$\left(72^{\circ} \mathrm{C}, 10 \mathrm{~min}\right)$ with 35 cycles. Sequencing by the Sanger method was carried out in a Life Technology 3139 XL type sequencer with 16 capillaries.DNA sequences were compared to those of the Genbank collection by using the WU-BLAST (Washington University-Basic Local Alignment Search Tool) algorithm (Altschul et al., 1997).

\section{Morphological and cultural characteristics of mycelium}

Morphological characteristics of the fungi were evaluated on PDA, malt extract agar (MEA) and $\mathrm{V}_{8}$ juice agar $(10 \%)$ medium. PDA and $\mathrm{V}_{8}$ juice media were prepared based on Rodrigues et al., (2010) protocol while Pradeep et al., (2013) protocol was used for preparation of MEA medium. A volume of 20 $\mathrm{ml}$ sterilized medium was poured in each Petri plate and allowed to solidify. Then, $5 \mathrm{~mm}$ diameter plugs were taken with the help of a cork borer from the margin of 7-days old isolates grown on PDA, and placed at the centre of each set of Petri plates containing different media. Petri dishes were incubated at $10,23,28$ and $33^{\circ} \mathrm{C}$. The diameter (in $\mathrm{mm}$ ) of each isolate was recorded in two directions at right angles to each other and then average colony diameter was calculated.

Growth was measured daily until the full expansion of the culture using the formula: $\mathrm{DG}=\left[\left(\mathrm{MDd}_{1}-\mathrm{MDd}_{0}\right)+\left(\mathrm{MDd}_{2}-\mathrm{MDd}_{1}\right)+\ldots+\right.$ $\left.\left(\mathrm{MDd}_{\mathrm{n}}-\mathrm{MDd}_{\mathrm{n}-1}\right)\right] / \mathrm{n}$, where $\mathrm{DG}$ is the daily growth rate, $\mathrm{MDd}_{\mathrm{n}}$ is the mean diameter growth of the $\mathrm{n}^{\text {th }}$ measurement day, $\mathrm{MDd}_{\mathrm{n}}=$ $\left(\mathrm{d}_{1}+\mathrm{d}_{2}\right) / 2$ where $\mathrm{d}_{1}$ is the first diameter measure on Petri dish and $\mathrm{d}_{2}$, the second. $\operatorname{MDd}_{0}=$ initial diameter of the mycelium disk which is $5 \mathrm{~mm}$ (Pandey et al., 1985; Singh et al., 1993). The appearance of colonies and pigmentation, the vegetative and reproductive structures were described after 10 days of incubation. The experiment was repeated three times for each culture medium and isolate.

\section{Microscopic characteristics of mycelium and conidia}

Microscopic observations of mycelium and conidia of each fungus on each culture medium and temperature was made using a Olympus BX-41 microscope (Carsen, Markham, ON, Canada) and photographs were taken with a digital camera(Media Cybernetics, Evolution model VF) connected to a computer. A $10 \mathrm{ml}$ conidial suspension was prepared by pouring sterile distilled water on 10-days old culture in Petri dishes. The concentration of spores (number of conidia/ml of suspension) was assessed for each culture medium and temperature from a drop of conidia suspension deposited on the hemocytometer. This activity was repeated three times. The size (width and length) of spores was measuredon30conidia of each species randomly selected using the graduated dial of the ocular of a light microscope and the number of cells per conidia was counted (Bakry et al., 2010). Morphological characteristics of spores were compared with those described in the literature (Pavlic et al., 2004; Hussain et al., 2012; Rahman et al., 2012).

\section{Statistical analysis}

Data obtained were subjected to one way analysis of variance (ANOVA) and means compared by Student Least Significant Difference (LSD) test at 5\% using SAS software (version 9.2).

\section{Results and Discussion}

\section{Sequencing and BLAST}

Data obtained from sequencing are presented in table 1. Isolates used are from bimodal rain forest and high plateau agroecological zones collected either on infected leaves or stem of $R$. heudelotii in crop farm, ICRAF plantation, 
cocoa farms and Applied Research Farm of the Faculty of Agronomy and Agricultural Science.

\section{Effect of culture media and temperature on morphological characteristics of fungi}

The culture medium influenced the radial growth of fungi. F. oxysporum isolates grew faster on MEA and PDA media compared to $\mathrm{V}_{8}$ juice agar except isolate FOBR_164S. No significant difference was observed in the growth of $L$. theobromae on the three culture media. The growth rate of $P$. microspora was high on $\mathrm{V}_{8}$ juice medium (Table 2). Among the isolates of $F$. oxysporum, the colour and the physical aspect of the mycelium varied from one medium to another; the mycelium was whitish and abundant on PDA and MEA

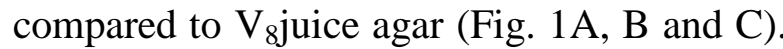
Mycelium of $P$. microspora and $L$. theobromae produced black pycnidia on PDA and MEA (Fig. 1D) and on PDA (Fig. 1E), respectively. It was observed that all the isolates of $F$. oxysporum growth at all the temperatures tested. At 10 and $33^{\circ} \mathrm{C}$, the mycelial growth was localized around the inoculum plugs, showing a whitish colour and a rosette appearance while at 23 and $28^{\circ} \mathrm{C}$, the mycelium is abundant. At $28^{\circ} \mathrm{C}$, the colour of the mycelium of $F$. oxysporum varied from one isolate to another; it was whitish to purple in FOBR_049L, whitish in FOBR_164S and purple to violet (highly pigmented) in FOHP_121L (Fig. 2A, B and C). Fungal growth was lower at 10 and $33^{\circ} \mathrm{C}$ in all culture media for all the fungi. In this experiment, the optimal growth temperature for $F$. oxysporum isolates was $28^{\circ} \mathrm{C}$ in the three culture media (Figure 2). Fungal growth rate was lowest at 10 and $33^{\circ} \mathrm{C}$ in all the culture media and for all the isolates. In $L$. theobromae, the maximum growth rate was at $23^{\circ} \mathrm{C}$ in all the culture media while in $P$. microspora and $F$. oxysporum isolates (FOZB049F, FOZB164T and FOZH121F), the optimum growth rate was at $28^{\circ} \mathrm{C}$ in the three culture media (Figure 3).

The size of conidia varied among isolates of $F$. oxysporum. The width and length of microconidia and macroconidia forFOBR_049L isolate on PDA varied from 2.2-3.9 $\mu \mathrm{m} \times 3-17.4 \mu \mathrm{m}$ and 3.7-4.2 $\mu \mathrm{m} \times 26-$ $28.5 \mu \mathrm{m}$, respectively. Isolate FOHP_121L produced longer macroconidia than other isolates (Table 3). Microconidia in $F$. oxysporum are mono or multicellular (2-3 cells) while macro conidia are multicellular (4-10 cells). There was abundant production of chlamydospores in FOBR_049L isolate in $\mathrm{V}_{8}$ juice agar (Figure 3). The number of cells reached 10 macroconidia in FOHP_121L while the maximum was 7 in FOBR_049L and FOBR_164S (Figures 4, 5 and 6). Isolate FOHP_121L produced microconidia and macroconidia that were longer and wider than those of FOBR_049L and FOBR_164S. The width and length of microconidia of FOHP_121L ranged from 2.2-4.4 $\mu \mathrm{m} \times 6$ $12.3 \mu \mathrm{m}, 2.3-4.6 \mu \mathrm{m} \times 7-23.5 \mu \mathrm{m}$ and 2-3.6 $\mu \mathrm{m} \times 6.3-11 \mu \mathrm{m}$ on PDA, MEA and $\mathrm{V}_{8}$ juice agar media, respectively. The size of macroconidia ranged from 3.1-5.3 $\mu \mathrm{m} \times 26-$ $42.2 \mu \mathrm{m}, 4.2-6.5 \mu \mathrm{m} \times 25.6-43 \mu \mathrm{m}$ and 2.9-4.9 $\mu \mathrm{m} x 26.8-39 \mu \mathrm{m}$ on PDA, MEA and $\mathrm{V}_{8}$ juice agar media, respectively (Table 3 ). On PDA, conidia of $P$. microspora were hyaline, bi- to tetra cellular with a cylindrical carrot-like shape; the tapered lower end terminated in a filamentous appendage while the more rounded upper end was extended by 2, 3 or 4 filaments (Fig. 7A). Conidia of $L$. theobromae were larger and brown with a peanut podshaped (Fig. 7B). The width and length of the conidia of $L$. theobromae and P. microspora are relatively thicker and longer on MEA medium compared to other media. In fact, conidia size of $L$. theobromae varied from 10.4 to $15.7 \mu \mathrm{m} \times 25.3$ to $30.2 \mu \mathrm{m}, 11$ to 17 $\mu \mathrm{m} \times 22.1-35.3 \mu \mathrm{m}$ and from 9.9-14.7 $\mu \mathrm{m} \times$ 18-27.8 $\mu \mathrm{m}$ on PDA, MEA and $\mathrm{V}_{8}$ 
respectively while in $P$. microspora, they varied from $6.6-7.8 \mu \mathrm{m} \times 18.7-29 \mu \mathrm{m}, 8-$ $12.9 \mu \mathrm{m} \times 22.1-38.6 \mu \mathrm{m}$ and from $6.5-$ $8.8 \mu \mathrm{m} \times 20.5-28 \mu \mathrm{mon}$ PDA, MEA and $\mathrm{V}_{8}$ juice agar media, respectively (Table 4).

\section{Effect of temperature on the concentration of fungal spores}

Temperature affected the concentration of fungal spores produced on all three culture media. In general, spore concentration increased with temperature until an optimum $\left(28^{\circ} \mathrm{C}\right)$, and then decreased until no more spore production occurred at $33^{\circ} \mathrm{C}$ for $P$. microspora and L. theobromae. However, $F$. oxysporum isolates continued to grow and produce spores at $33^{\circ} \mathrm{C}$. Significant differences in spore concentration were observed between $28^{\circ} \mathrm{C}$ and the other temperatures $\left(10,23\right.$ and $\left.33^{\circ} \mathrm{C}\right)$ for isolates FOBR_049L and FOHP_121L of $F$. oxysporum. In contrast, no significant difference was observed in spore's concentration of FOHP_164S at 23 and $28^{\circ} \mathrm{C}$ on the MEA and $\mathrm{V}_{8}$ juice agar media. There was also no significant difference in spore concentration between 21,23 and $28^{\circ} \mathrm{C}$ for $P$. microspora on PDA and for L. theobromae on PDA, MEA and $\mathrm{V}_{8}$ juice agar media.

Table.1 Ecological and molecular characteristics of fungal isolates used in the study

\begin{tabular}{llllll}
\hline Isolate code & Agro ecological zone & Locality & Ecological niche & $\begin{array}{l}\text { Plant } \\
\text { organ }\end{array}$ & ITS/BLAST $^{\text {a }}$ \\
\hline LTHP_110L & High Plateau & Bantoum III & Crop farm & Leaves & FJ904838.1 \\
PMHP_109L & High Plateau & Bantoum III & Crop farm & Leaves & AF377292.1 \\
FOBR_049L & Bimodal Rainforest & Yaoundé 7e & ICRAF plantation & Leaves & HM179532.1 \\
FOBR_164S & Bimodal Rainforest & Yokadouma & Cocoa farm & Stem & HQ658965.1 \\
FOHP_121L & High Plateau & Dschang & ARF, FASA & Leaves & GU724513.1 \\
\hline
\end{tabular}

${ }^{a}$ Sequences from public genbank (NCBI) with highest similarity with the sequence of fungal isolates from $R$. heudelotii. $\mathrm{L}=$ isolated from leaves and $\mathrm{S}=$ isolated from stem (seedlings). AFR, FASA= Applied Research Farm of the Faculty of Agronomy and Agricultural Science.

Table.2 Effect of culture media on the daily growth rate $(\mathrm{mm} / \mathrm{d})$ of fungal isolates incubated at $23^{\circ} \mathrm{C}$

\begin{tabular}{lccc}
\hline Isolate code and fungal species & \multicolumn{3}{c}{ Culture media } \\
\cline { 2 - 4 } & PDA & MEA & V $_{\mathbf{8}} \mathbf{( 1 0 \% )}$ \\
\hline LTHP_110L (Lasiodiplodia theobromae) & $21.6 \pm 2.3^{\mathrm{a}}$ & $20.6 \pm 1.2^{\mathrm{a}}$ & $19.8 \pm 0.9^{\mathrm{a}}$ \\
PMHP_109L (Pestalotiopsis microspora) & $10.0 \pm 1.1^{\mathrm{b}}$ & $9.7 \pm 1.4^{\mathrm{b}}$ & $13.4 \pm 1.7^{\mathrm{a}}$ \\
FOBR_049L (Fusarium oxysporum) & $8.4 \pm 1.2^{\mathrm{a}}$ & $8.1 \pm 0.8^{\mathrm{a}}$ & $6.3 \pm 0.8^{\mathrm{b}}$ \\
FOBR_164S (Fusarium oxysporum) & $7.8 \pm 0.9^{\mathrm{a}}$ & $8.6 \pm 1.6^{\mathrm{a}}$ & $6.9 \pm 0.6^{\mathrm{a}}$ \\
FOHP_121L (Fusarium oxysporum) & $9.8 \pm 1.9^{\mathrm{a}}$ & $9.1 \pm 0.7^{\mathrm{a}}$ & $7.0 \pm 1.2^{\mathrm{b}}$ \\
\hline
\end{tabular}

${ }^{\mathrm{a}, \mathrm{b}}$ Means follow by the same letter in the line are not significantly different based on Student's LSD at 5\%. LT: L. theobromae, PM: P. microspora and FO: F. oxysporum. HP: High Plateau, and BR: Bimodal Rainforest. L: isolate from leave and $\mathrm{S}$ : isolate from stem. 
Table.3 Micro and macro conidia sizes $(\mu \mathrm{m})$ of isolates of $F$. oxysporum on PDA milieu incubated at $21 \pm 1^{\circ} \mathrm{C}$ from 10-days old culture

\begin{tabular}{|c|c|c|c|c|c|c|c|c|c|c|c|c|}
\hline \multirow{3}{*}{$\begin{array}{l}\text { Isolates of } \\
\text { F. oxysporum }\end{array}$} & \multicolumn{4}{|c|}{ PDA } & \multicolumn{4}{|c|}{ MEA } & \multicolumn{4}{|c|}{$\mathrm{V}_{8}$} \\
\hline & \multicolumn{2}{|c|}{ Microconidia } & \multicolumn{2}{|c|}{ Macroconidia } & \multicolumn{2}{|c|}{ Microconidia } & \multicolumn{2}{|c|}{ Macroconidia } & \multicolumn{2}{|c|}{ Microconidia } & \multicolumn{2}{|c|}{ Macroconidia } \\
\hline & Width & Length & Width & Length & Width & Length & Width & Length & Width & Length & Width & Length \\
\hline FOBR-049L & $2.2-3.9$ & $3-17.4$ & $3.7-4.2$ & $26-28.5$ & $1.2-3.1$ & $4.4-20$ & $4.3-4.6$ & $26.7-29$ & $2.1-3.8$ & $4.8-21$ & $3.3-4.4$ & $25-26.7$ \\
\hline FOBR-164S & $1.7-3.1$ & 4.6-19 & 3- 4.4 & $21-30.4$ & $1.9-3.5$ & $4.8-21$ & $3.3-5.1$ & $20.6-33$ & $1.9-2.8$ & 4.3-19 & $2.6-4.1$ & $21-29.3$ \\
\hline FOHP-121L & $2.2-4.4$ & $6-12.3$ & $3.1-5.3$ & $26-42.2$ & $2.3-4.6$ & $7-23.5$ & $4.2-6.5$ & $25.6-43$ & $2-3.6$ & 6.3-11 & $2.9-4.9$ & 26.8-39 \\
\hline
\end{tabular}

Table.4 Conidia sizes $(\mu \mathrm{m})$ of Lasiodiplodia theobromae and Pestalotiopsis microspora on PDA, MEA and $\mathrm{V}_{8}$ media incubated at $21 \pm 1$ oCfrom 10 days-old- culture

\begin{tabular}{|c|c|c|c|c|c|c|}
\hline \multirow[t]{2}{*}{ Isolates } & \multicolumn{2}{|c|}{ PDA } & \multicolumn{2}{|c|}{ MEA } & \multicolumn{2}{|c|}{$\mathbf{V}_{8}$} \\
\hline & Width & Length & Width & Length & Width & Length \\
\hline $\begin{array}{l}\text { LTHP-110 L } \\
\text { (Lasiodiplodia theobromae) }\end{array}$ & 10.4-15.7 & $25.3-30.2$ & $11-17$ & $22.1-35.3$ & $9.9-14.7$ & $18-27.8$ \\
\hline $\begin{array}{l}\text { PMHP-109L } \\
\text { (Pestalotiopsis microspora) }\end{array}$ & $6.6-7.8$ & $18.7-29$ & 8-12.9 & $22.1-38.6$ & $6.5-8.8$ & $20.5-28$ \\
\hline
\end{tabular}


Figure.1 Variation of morphological characteristics of fungi on different culture media. A: FOBR_049L isolate (F. oxysporum), B: FO_BR164S isolate $(F$. oxysporum), C: FOHP_121Lisolate $(F$. oxysporum), D: PMHP_109L isolate $(P$. microspora $)$ and E: LTHP_110Lisolate (L. theobroma). Fungi were incubated at $23^{\circ} \mathrm{C}$ during 6days; arrows indicate fructifications
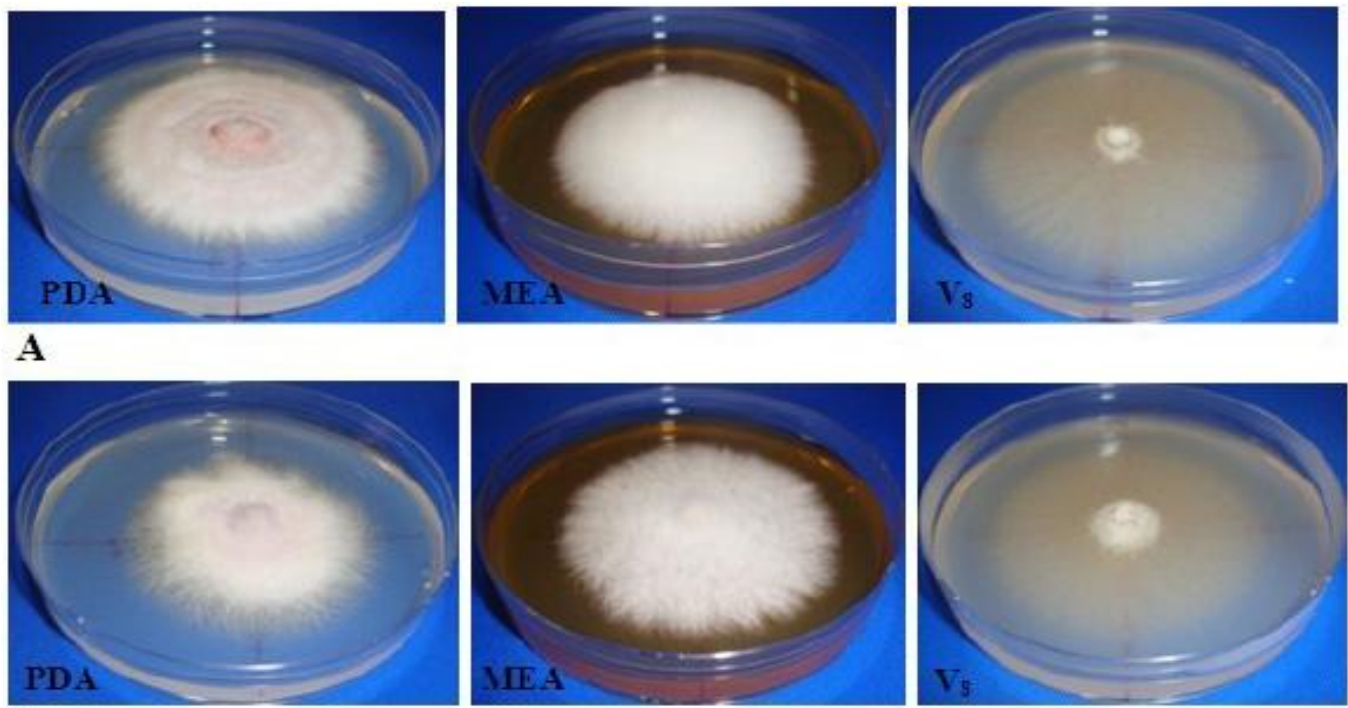

B
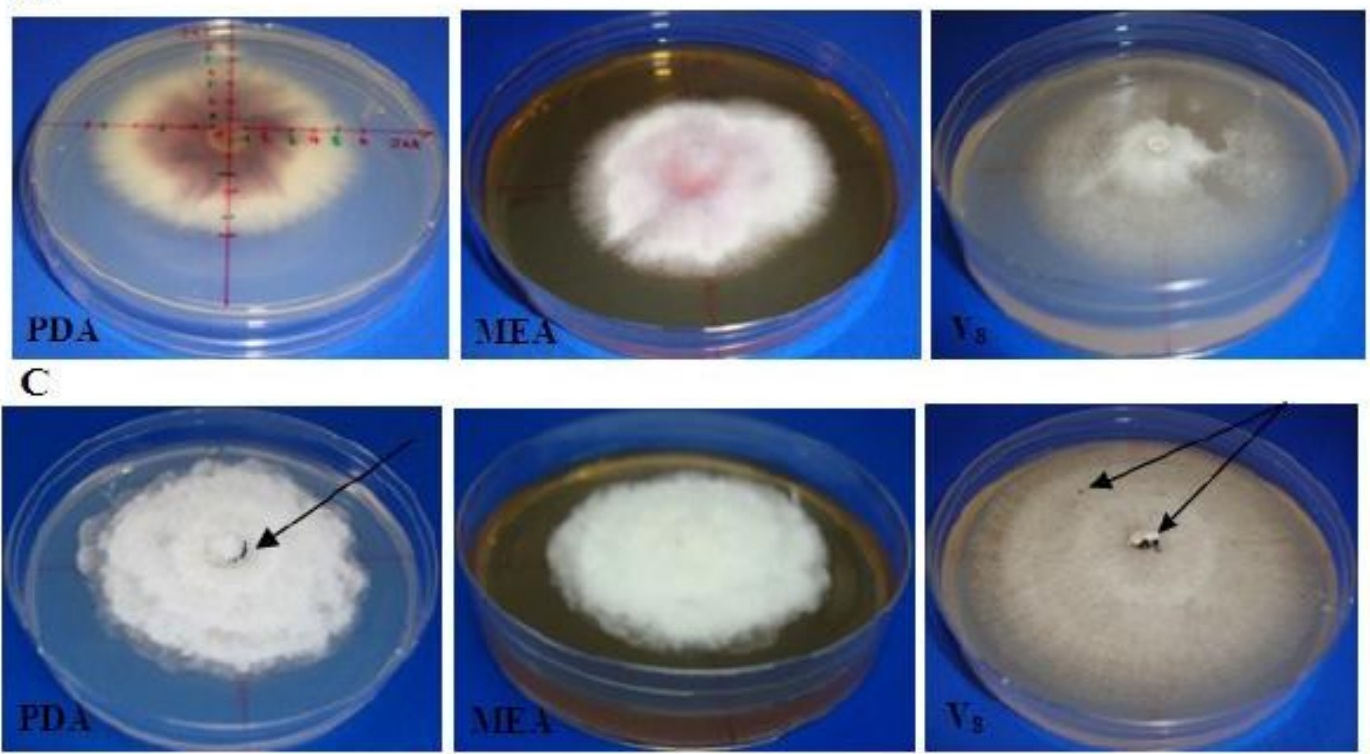

D
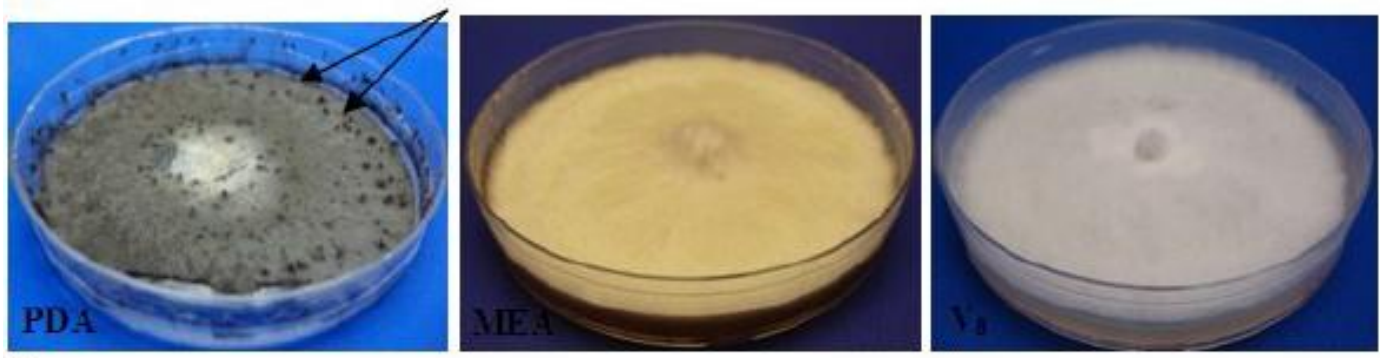

$\mathbf{E}$ 
Figure.2 Variation of morphological characteristics among Fusarium oxysporum isolates based on temperature of incubation. A: FOBR_049L, B: FOBR_164SandC: FOBR_121L. The culture medium in the 1st and last column is PDA while the medium in the 2nd and 3rd column is MEA
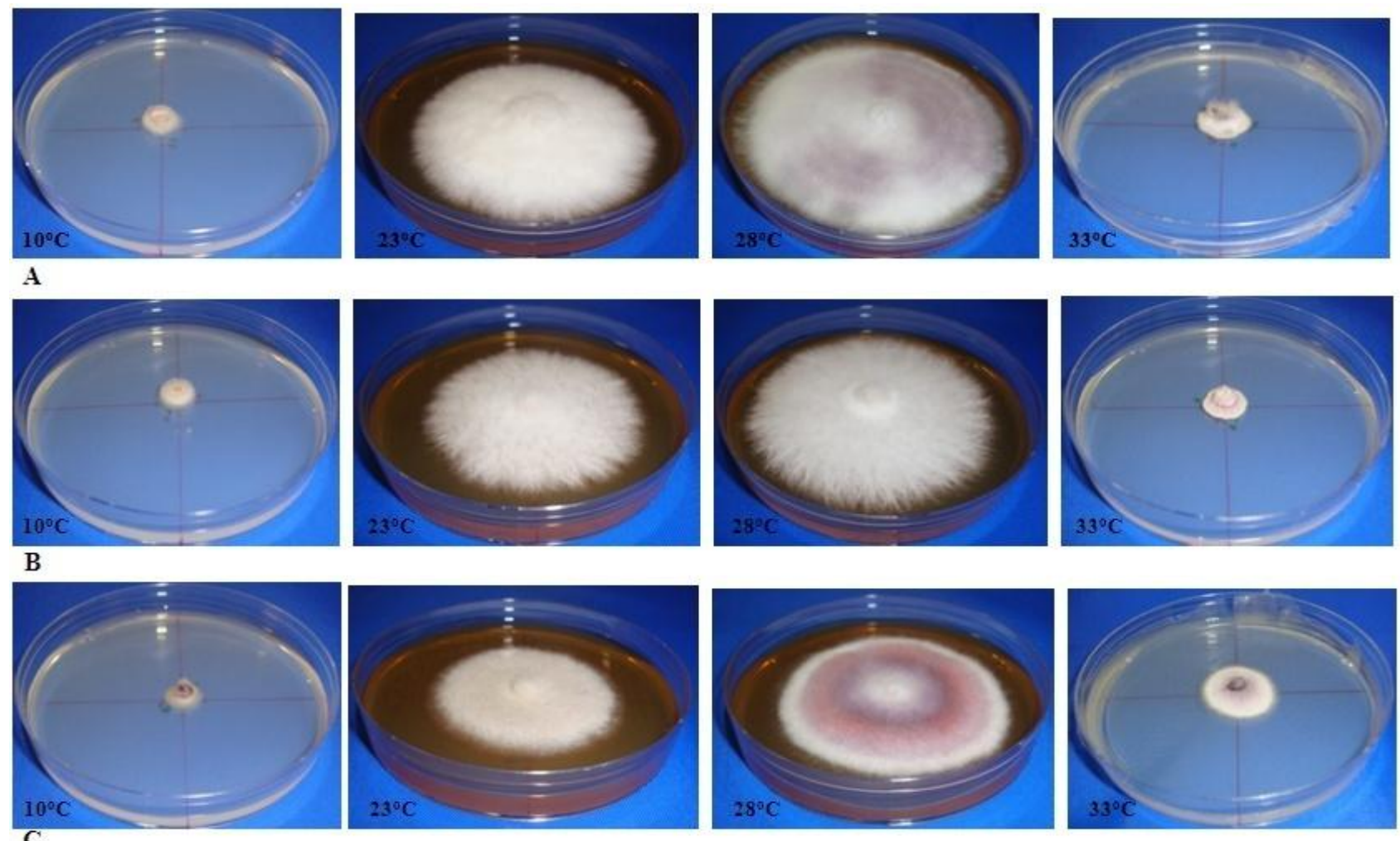

Figure.3 Evolution of growth rate (mm/day) of fungi newly recorded from Ricinodendron heudelotii on PDA, MEA and $\mathrm{V}_{8}$ media at different incubation temperatures
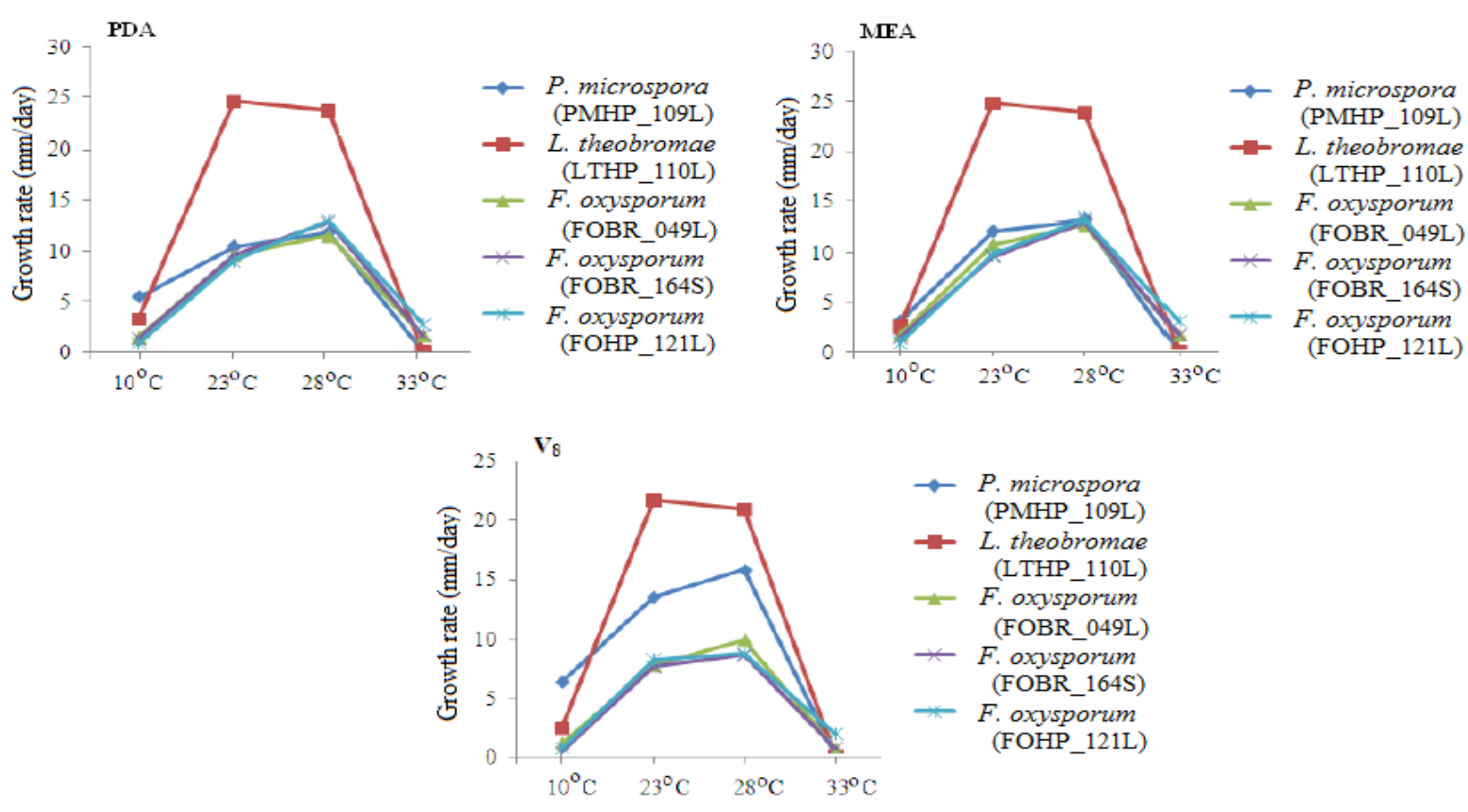
Figure.4 Micro and macro conidia of Fusarium oxysporum (isolate FOBR_049L) on PDA and MEA media. Chlamydospores on $\mathrm{V}_{8}$ Agar medium from14-day-old culture, 400X; gentian violet as mounting liquid
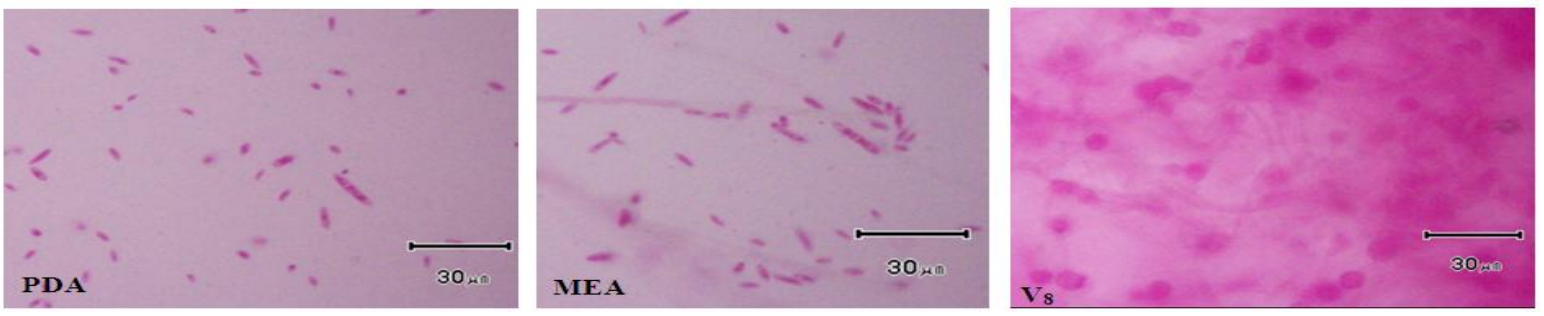

Figure.5 Micro and macro conidia of Fusarium oxysporum (isolate FOBR_164S), from infected stem of seedlings of Ricinodendron heudelotii incubated at 21oC on PDA, 400X; water as mounting liquid

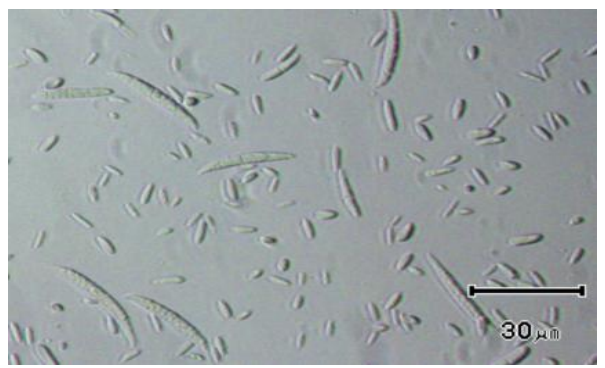

Figure.6 Micro and macro conidia of Fusarium oxysporum FOHP_121Lfrom infected leaves of seedlings of Ricinodendron heudelotii incubated at 10, 28 and 33oC on PDA, 400X; water as mounting liquid
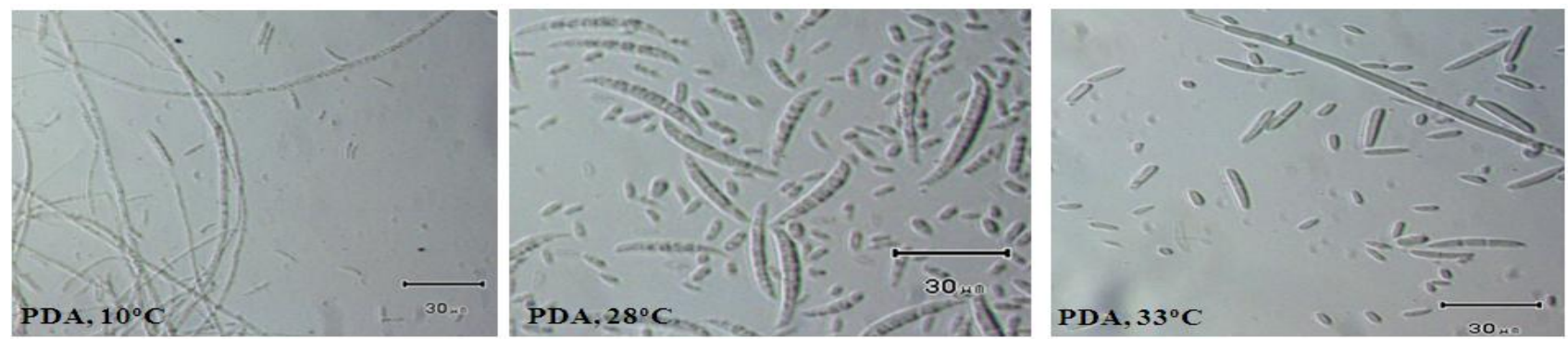

Figure.7 Conidia of Pestalotiopsis microspora (A) and Lasiodiplodia theobromae (B) isolated from Ricinodendron heudelotii incubated at $23^{\circ} \mathrm{C}$ on PDA medium, 400X; water as mounting liquid
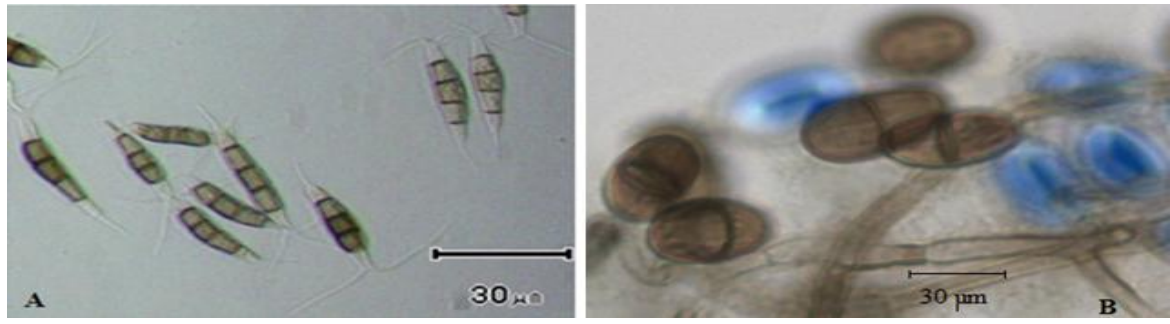
Figure.8 Concentration of spores of fungi isolated from Ricinodendron heudelotii and incubated during 14 days on PDA, MEA and $\mathrm{V}_{8}$ media. Means follow by the same letter in one fungal species are not significantly different based on Student's test at 5\%
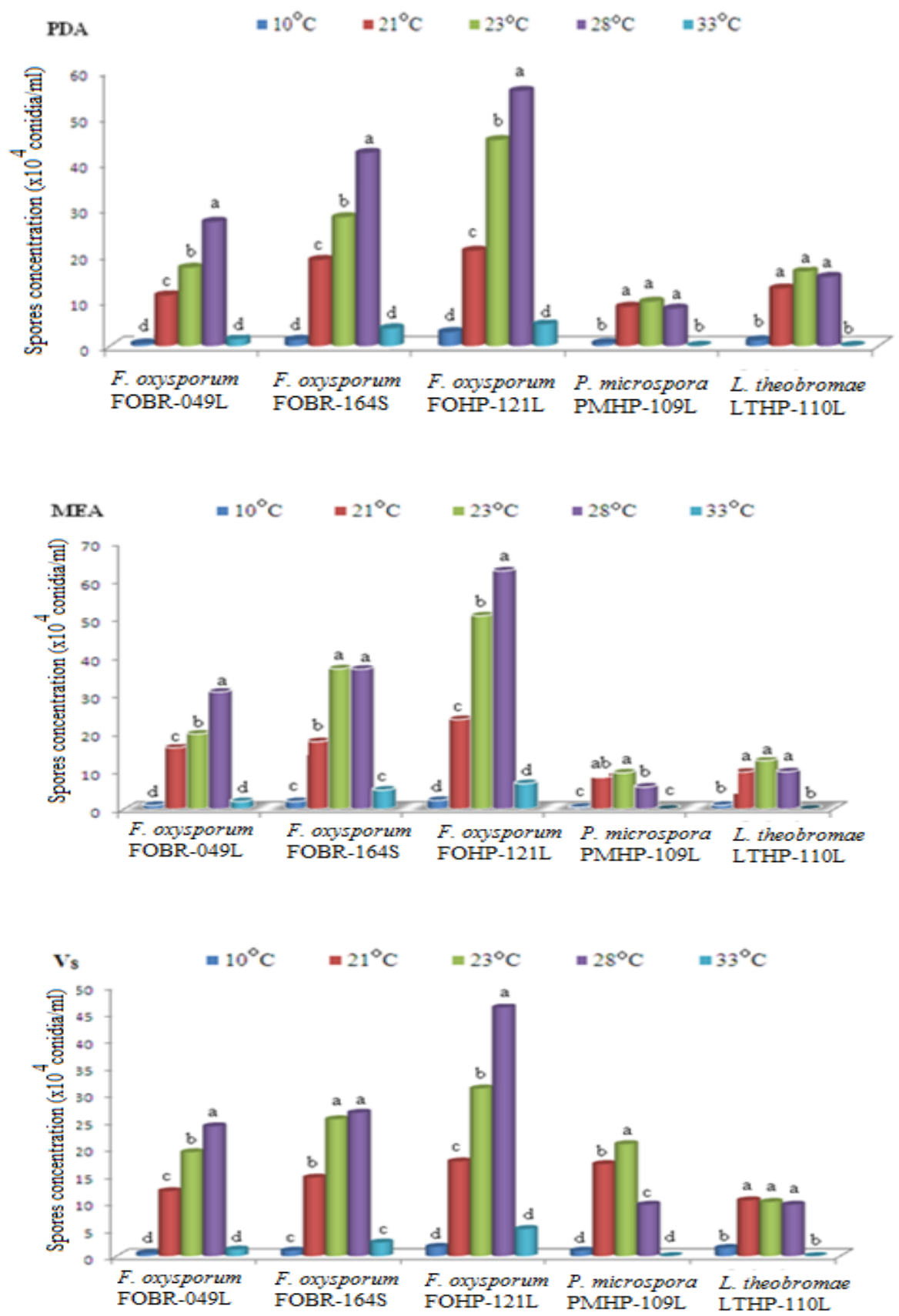

However, spore concentration was The study reveals marked differences in the significantly higher in these three temperatures and media compared to $10^{\circ} \mathrm{C}$ and $33^{\circ} \mathrm{C}$ for $L$. theobromaeand $P$. microspora (Figure 8). mycelial growth and sporulation patterns for the three fungal species tested on three culture media that are routinely used in plant pathology laboratories. Culture medium and temperature affected the morphocultural 
characteristics of the fungi tested. Indeed, preferences of fungi vis-a-vis the culture medium and temperature varied among species and, within Fusarium oxysporum, from one isolate to another. Some fungi grow and sporulate better on organic media incubated at low or high temperature, others on more selective media. It is known that temperature affects the number of spores produced on the culture medium (Agrios, 2005; Rahman et al., 2012). Mycelial growth and sporulation were abundant on PDA, MEA and $\mathrm{V}_{8 j}$ uice agar media. These media are organic substrates rich in carbohydrates which are source of energy for cell metabolism, growth and sporulation of fungi. Several workers have recognized the importance of various organic media for mycelial growth and spore production in fungi (Kim et al., 2005; Zhao et al., 2010; Pradeep et al., 2013). PDA is one of the most commonly used culture media because of its simple formulation and its ability to support mycelial growth of a wide range of fungi. Several researchers state that PDA is one of the best media for mycelial growth of many fungi followed by MEA (Xu et al., 1984; Maheshwari et al., 1999; Khadega and AlHussaini, 2015). $\mathrm{V}_{8}$ juice agar was also reported as suitable for cultivation and sporulation of other fungal species like Mycosphaerella fijiensis, $M$. musicola, Phomamacdon aldii and Phytophthora spp (Medina and Platt, 1999; Drenth and Sendall, 2001; Abadie et al., 2005; Al Fadil, 2006; Tsompbeng et al., 2012). Morphological traits (mycelia appearance, conidium size and pigmentation of mycelium) observed in isolates of $F$. oxysporum from $R$. heudelotii are comparable at some extend to those reported in other $F$. oxysporum (Sharma et al., 2005; Hussain et al., 2012). Isolates of $F$. oxysporum from wilted guava grow and sporulate abundantly with production of chlamydospores on PDA medium at 20 and $25^{\circ} \mathrm{C}$ (Hussain et al., 2012) while corn meal agar medium was reported to be suitable for the growth of Fusarium oxysporum f. sp. cubense on which length of microconidia and macroconidia reached 12.9 and $57.4 \mu \mathrm{m}$, respectively (Rahman et al., 2012).

The range of temperatures (from 10 to $33^{\circ} \mathrm{C}$ ) at which isolates of $F$. oxysporum from $R$. heudelotii could grow and sporulate indicates that this pathogen possesses a high level of phenotypic plasticity that allows it to survive and proliferate over a wide range of environmental conditions. The optimal temperature of mycelial growth for $F$. oxysporum isolates was $28^{\circ} \mathrm{C}$. This was also reported in $F$. moniliforme KUMBF 1201 isolate cultivated on PDA and potato dextrose broth media and isolated from paddy field soil in India (Pradeep et al., 2013) and in Fusarium oxysporum f. sp. psidii and $F$. solani, causal agents of wilt in guava cultivated on PDA (Gupta et al., 2010). However, it was established that Fusarium species like $F$. oxysporum f. sp. narcissi can growth at $45^{\circ} \mathrm{C}$ in liquid medium (Linfield, 1986).

Conidia sizes in P. microspora isolated from $R$. heudelotii are relatively similar to values reported for 16 isolates of the same fungus isolated from Taxodium distichum and incubated on PDA at $23^{\circ} \mathrm{C}(\mathrm{Li}$ et al., 1996), and for isolates from Psidium guajava grown on PDA at $24^{\circ} \mathrm{C}$ (Keith et al., 2006). However, Keith et al.(2006) reported that all isolates of $P$. Microspora from $P$. guajava grew at temperatures ranging from 10 to $35^{\circ} \mathrm{C}$ and that the optimum growth temperature differed among isolates and varied between 22and $28^{\circ} \mathrm{C}$. In our study, L. theobromae and P. microspora failed to grow at $33^{\circ} \mathrm{C}$ probably due to the inactivation of enzymes by temperature increase with a resulting effect on metabolism which affects growth (Mishra et al., 2013; Pathak et al., 2014). The optimum growth temperature for 
P. microspora isolate was $23^{\circ} \mathrm{C}$ on $\mathrm{PDA}$, MEA and $\mathrm{V}_{8}$ juiceagar media. Morphocultural characters and sizes of conidia in L. theobromae are similar to those described by Pavlic et al., (2004) and Shah et al., (2010) for cultures isolated from infected cocoa (Theobromae cacao L.) and avocado (Perseaa mericana L.), respectively. Conidial sizes of $L$. theobromae ranged from 11-15 $\mu \mathrm{m}$ $\mathrm{x} 20-35 \mu$ mon MEA medium at $25^{\circ} \mathrm{C}$ (Pavlic et al., 2004).

For all the fungi, it was observed that as temperature increased, mycelial growth and spore production also increased but at $28^{\circ} \mathrm{C}$ they started to decline for $F$. oxysporum and $23^{\circ} \mathrm{C}$ for $P$. microspora and $L$. theobromae on PDA, MEA and $\mathrm{V}_{8 j}$ juice agar media. This could be attributed to increase in enzymatic activity of the fungi.

In conclusion, this study revealed that culture media differentially influence the growth, colony characteristics (physical aspect and pigmentation of the mycelium) and sporulation of $P$. microspora, L. theobromae and $F$. oxysporum recovered from $R$. heudelotii. Among the test media used in the present study, PDA and MEA were found to be most suitable for mycelial growth and sporulation of $F$. oxysporum while $\mathrm{V}_{8}$ juice agar was suitable for $P$. microspora and the three media were appropriate for $L$. theobromae. The optimum temperature for high production of spores was $28^{\circ} \mathrm{C}$ for $F$. oxysporum isolates and $23^{\circ} \mathrm{C}$ for $P$. microspora and $L$. theobromae. These data will be important for future large-scale studies involving cultural and morphological characterization of more isolates of these newly recorded fungi from $R$. heudelotii.

\section{Acknowledgement}

Financial support of the Phytopathology Laboratory of the University of Dschang and the technical assistance of the Molecular Biology Laboratory of the Universite Laval in Quebec (Canada) are greatly acknowledged.

\section{References}

Abadie, C., L. Pignolet, A. Elhadrami, R. Habas, M-F. Zapater and Carlier J. 2005.Inoculation avec Mycosphaerella sp., agent de cercosporioses de fragments de feuilles de bananiers maintenus en survie. Cahier des Techniques 2005: 131-134.

Agrios, G.N. 2005. Plant pathology. $5^{\text {th }}$ edn. Elsevier Academic Press, California, USA, $922 \mathrm{Pp}$.

Al Fadil, T.A. 2006. Déterminisme de la tolérance du tournesol à Phoma macdonaldii au collet et sur racines: approches génétiques et histologiques. Thèse de Doctorat, Ecole Nationale Supérieure Agronomique de Toulouse, Toulouse, France.

Altschul, S.F., T.L. Madden, A.A. Schäffer, J. Zhang, Z. Zhang, W. Miller and Lipman, D.J. 1997. Gapped BLAST and PSI-BLAST: a new generation of protein data base search programs. Nucleic Acids Research 25: 33893402.

Bakry, M., G. Bussières, M.S. Lamhamedi, H.A. Margolis, D.C. Stowe, M. Abourouh, M. Blais and BérubéJ.A. 2010. A first record of Pestalotiopsis clavispora in Argan mass cutting propagation: Prevalence, prevention and consequences for plant production. Phytoprotection, 90: 117120.

Djeugap, J.F., J.R. Kuiate and Fontem D.A. 2009.Etat sanitaire post-récolte de la mangue commercialisée à Dschang et efficacité in vitro de quelques huiles essentielles contre Colletotrichum gloeosporioides, agent de l'anthracnose. Annales de la $9^{\text {ème }}$ 
Conférence Internationale des maladies des Plantes, Tours, France, Pp. 77-80.

Djeugap, F.J. 2013. Contraintes de germination et diagnostic moléculaire des champignons associés aux maladies chez Ricinodendron heudelotii au Cameroun. Thèse de Doctorat/PhD, Université Laval, Québec, Canada, 183 Pp.

Djeugap, F.J., L. Bernier, D. Dostaler, D. Khasa, D.A. Fontem and Nwaga, D. 2013. Opportunités et contraintes agroforestières de Ricinodendron heudelotii au Cameroun. International Journal of Biological and Chemical Science 7(1): 344-355.

Djeugap, F.J., L. Bernier, D. Dostaler and Zena D.G.R. 2016. First report of Lasiodiplodia theobromae causing shoot blight of Ricinodendron heudelotii seedlings in Cameroon. International J. Agronomy Agricult. Res., 8(1): 59-63.

Drenth, A. and Sendall B. 2001.Practical guide to detection and identification of Phytophthora. Version 1.0 CRC for Tropical Plant Protection, Brisbane, Australia, 42p.

Gezahgne, A., A. YirguandKassaH. 2014. First report of Lasiodiplodia theobromae causing canker on tapped Boswellia papyrifera trees in Ethiopia. New Disease Reports 29:11.

Griffin, D.W., C.A. Kellogg, K.K. Peak and Shinn E.A. 2002. A rapid and efficient assay for extracting DNA from fungi. Letters in Applied Microbiology 34: 210-214.

Gupta, V.K., A.K. Misra and Gaur R.K. 2010. Growth characteristics of Fusarium spp. causing wilt disease in Psidium guajava L. in India. Journal of Plant Protection Research 50(4): 452-462.

Hussain, M.Z., M.A. Rahman, M.N. Islam, M.A. Latif and Bashar M.A. 2012.
Morphological and molecular identification of Fusarium oxysporum Sch. isolated from guava wilt in Bangladesh. Bangladesh Journal of Botany 41: 49-54.

Keith, L.M., M.E. Velasquez and Zee, F.T. 2006. Identification and characterization of Pestalotiopsisspp. causing scab disease of guava, Psidium guajava, in Hawaii. Plant Disease 90: 16-23.

Kim, Y.K., C.L. Xiao and RogersJ.D.2005. Influence of culture media and environmental factors on mycelial growth and pycnidial production of Sphaeropsis Mycologia, 97: 25-32.

pyriputrescens.

Khadega, H.K. and Al-Hussaini, I.M. 2015. Diagnostic and environmental study of Aspergillus terreus isolated from various varieties of apples fruits. Journal of Contemporary Medical Sciences 1(4): 31-35.

Kuhn, D.M. and Ghonnoum, M.A. 2003. Indoor mold, toxigenic fungi, and Stachybotrys chartarum: Infectious disease perspective. Clinical Microbiology Reviews 16(1): 144-172.

Kumara, K.L.W. and Rawal, R.D. 2008. Influence of carbon, nitrogen, temperature and $\mathrm{pH}$ on the growth and sporulation of some Indian isolates of Colletotrichum gloeosporioides causing anthracnose disease of papaya (Carrica papaya L.). Tropical Agricultural Research and Extension 11: 7-12.

Levy, L. and Mavrodieva, V. 2004.PCR detection and DNA isolation methods for use in the Phytophthora ramorum national program. DNA and PCR Protocol elaborated at Oregon State University and the University of California at Berkeley for $P$. ramorum, $11 \mathrm{p}$.

Li, J.Y., G. Strobel, R. Sidhu, W.M. Hess and 
Ford, E.J. 1996. Endophytic taxolproducing fungi from bald cypress, Taxodium distichurn L. Microbiology, 142: 2223-2226.

Linfield, 1986. A comparison of the effects of temperature on the growth of Fusarium oxysporum f. sp. narcissi in solid and liquid media. Journal of Phytopathology, 116(3): 278-281.

Maheswari, S.K., D.V. Singh and Sahu A.K. 1999. Effect of several nutrient media, $\mathrm{pH}$ and carbon sources on growth and sporulation of Alternaria alternata. Journal of Mycopathological Research, 37: 21-23.

Medina, M.V. and Platt H.W. 1999. Comparison of different culture media on the mycelial growth, sporangia and oospore production of Phytophthora infestans. American Journal of Potato Research 76: 121-125.

Mishra, S., P. Kumar and Malik, A. 2013. Effect of process parameters on the enzyme activity of a novel Beauveria bassiana isolate. International Journal of Current Microbiology Applied Science 2(9): 49-56.

Mohali, S., T. Burgess and Wingfield M.J. 2005. Diversity and host association of the tropical tree endophyte Lasiodiplodia theobromae revealed using simple sequence repeat markers. Forest Pathology, 35: 385-396.

Pandey, R.R. and Dwivedi, R.S. 1985. Fusarium oxysporumf. sp. psidiias a pathogen causing wilt of guava (PsidiumguajavaL.) in Varanasi district, India. Phytopathologische Zeitschrift, 114: 243-248.

Pathak, S.S., S. Kumar, R.C. Rajak and Sandhu, S.S. 2014.Study of effect of temperature on amylase production by soil mycotic flora of Jabalpur region. World Journal of Pharmacy and Pharmaceutical Sciences 3 (9): 14481458.
Pavlic, D., B. Slippers, T.A. Coutinho, M. Gryzenhout and Wingfield, M.J. 2004.Lasiodiplodia gonubiensis sp. nov., a new Botryosphaeria anamorph from native Syzygium cordatum in South Africa. Studies in Mycology, 50: 313-322.

Pradeep, F.S., M.S. Begam, M. Palaniswamy and Pradeep, B.V. 2013. Influence of culture media on growth and pigment production by Fusarium moniliforme KUMBF 1201 isolated from paddy field soil. World Applied Sciences Journal, 22(1): 70-77.

Rabbani, N., R. Bajwa and Javaid, A. 2011. Influence of culturing conditions on growth and sporulation of Drechslera hawaiiensis, the foliar blight pathogen of Marsileaminuta. African Journal of Biotechnology, 10(10): 1863-1872.

Rahman, N.R.B., K. Ahmadi, P. Lepun, Z. Rosli, A. Abdu and King, W.S. 2012.Effects of culture media on growth and spore occurrence of Fusarium oxysporum f. sp. Cubense (E.F. Smith) W.C. Snyd. and H.N. Hans. Asia Life Sciences 21: 133-148.

Rodrigues, T.T.M.S., L.A. Maffia, O.D. Dhingra and Mizubuti, E.S.G. 2010. In vitro production of conidia of Alternaria solani. Tropical Plant Pathology 35(4): 203-212.

Singh, G. R.K. Padhvay, G.S. Narayaman, K.P. Padmkumari and G.P. Rao (1993). Chemical and fungitoxic investigation on the essential oil of Citrus Pers. Z. Deutsche Zeits half fur Pflangenfrankenenen und Flanzenschultz, 100: 69-74.

Shah, M.D., K.S. Verma, K. Singh and Kaur, R. 2010. Morphological, pathological and molecular variability in Botryodiplodia theobromae (Botryosphaeriaceae) isolates associated with die-back and bark canker of pear trees in Punjab, India. 
Genetic Molecular Resources 9: 1217-1228.

Sharma, R.L., B.P. Singh, M.P. Thakur and Thapak S.K. 2005. Effect of media, temperature, $\mathrm{pH}$ and light on the growth and sporulation of Fusarium oxysporum f.sp. lini (balley) Snyder and Hansen. Annual Plant Protection Science 13: 172-174.

Tantaoui, A. and Fernandez, D. 1993. Comparaison entre Fusarium oxysporum f.sp. albedinis et Fusarium oxysporumdes sols des palmeraies par l'étude du polymorphisme de longueur des fragments de restriction (RFLP). Phytopathologie méditérannéenne, 32: 235-244.

Tsopmbeng, G.R., D.A. Fontem and Yamde K.F. 2012. Evaluation of culture media for growth and sporulation of Phytophthora colocasiae Racib., causal agent of taro leaf blight. International Journal of Biological and Chemical Science 6(4): 15661573.

White, T.J., T.D. Bruns, S. Lee and TaylorJ. 1990. Amplification and direct sequencing of fungal ribosomal RNA genes for phylogenetics. Pp 315-322 In: PCR Protocols: A Guide to
Methods and Applications. M.A. Innis, D.H. Gelfand, J.J. Sninsky, and T.J. White Eds. Academic Press, San Diego, Canada.

Xu, S.O., S.Z. Yuan and Chen X.C. 1984. Studies on pathogenic fungus (Alternaria tenuis Nees) of popular leaf blight. Journal of North East Forestry Institute 12: 56-64.

Yeboah, S.O., Y.C. Mitei, J.C. Ngila, L. Wessjohann and Schmidt J. 2011. Compositional and Structural Studies of the Major and Minor Components in three Cameroonian seed oils by GC-MS, ESI-FTICR-MS and HPLC. Journal of American Oil Chemistry Society 88: 1539-1549.

Zhang, M., H. Wu, T. Tsukiboshi and Okabe, I. 2010. First report of Pestalotiopsis microspora causing leaf spot of hidcote (Hypericum patulum) in Japan. Plant Disease 94(8): 1064.

Zhao, H., L. Huang, C.L. Xiao, J. Liu, J. Wei and Gao, X. 2010. Influence of culture media and environmental factors on mycelial growth and conidial production of Diplocarponmali. Letters in Applied Microbiology 50: 639-644.

\section{How to cite this article:}

Joseph Djeugap Fovo, Daniel Dostaler and Louis Bernier. 2017. Influence of Culture Media and Temperature on Growth and Sporulation of Lasiodiplodia theobromae, Pestalotiopsis microspora and Fusarium oxysporum Isolated from Ricinodendron heudelotii in Cameroon. Int.J.Curr.Microbiol.App.Sci. 6(6): 3098-3112. doi: https://doi.org/10.20546/ijcmas.2017.606.367 